\title{
Musical Taste and Preference of Students in Some Selected Colleges of Education in Ghana
}

\author{
Ndah Divine Selorm ${ }^{1}$, Adom Faith Mawunyo ${ }^{2}$, Jessica Amoah ${ }^{3}$ \\ ${ }^{I}$ SDA College of Education, Koforidua- Ghana Department of Creative Arts \\ ${ }^{2}$ St Francis College of Education, Hohoe, Ghana Department of Performing Arts \\ ${ }^{3}$ St Monica's College of Education, Ashanti Mampong- Ghana Department of Creative Arts \\ *Corresponding author
}

\begin{abstract}
There are many musical types that are found in Ghana. The primary ones are Art, Popular and Traditional musical types. This study sought to explain the differences that exist between these three musical types and also find out which of them is the preferred choice among students of some selected Colleges of Education in Ghana, so that, the students preferred musical type could be used to communicate with them in the academic space on the campuses. In order to seek the answers for the study, 300 students were sampled using Convenience and Random sampling techniques. With interview, questionnaire and Observation as the research instruments. The study revealed that, majority of the respondents like the Popular musical type over the Art and Traditional types. This could inform policy makers on education in the Colleges whether to use popular musical type as a teaching strategy since it goes down well with the majority of the student body.
\end{abstract}

Keywords: Musical types, Art Music, Popular Music, Traditional Music, Preference

\section{BACKGROUND TO THE STUDY}

$M$ usic and dance have been with African before the arrival of the European, who introduced formal education hence formal music. Many musical types are found in Ghana currently with the most known types such as the Art Music, Popular Music and the traditional types.

Even in the midst of formal education in recent days, traditional music for example still competes with other musical types. This confirms Agordor (2004) that despite the acculturation and pressures from music from other foreign world, traditional music still thrives well. Traditional musical types are those that have themes taken from the environment, and makes use of proverbs, riddles and figurative expressions within the immediate environment. Traditional music also deals with traditional establishments such as chieftaincy, festivals and funerals.

One major characteristics of these musical types is that they send messages out to their audience. According to Brewu (2009) the traditional musical type for example is related to the ethnic groups in Ghana. For example Adowa and Adzewa musical types are associated with Asante and Fanti ethnic groups respectively, Borborbor and Agbadza among the Ewe people. Ndwonkro musical type which is one of the oldest in Ghana could as well be associated with the Asante ethnic group. One thing worth noting about these musical type is that anyone among the audience who is originally not part of the performance is permitted to associate with the performance.

All the musical types whether Art, Popular or Traditional ensemble help in socializing the members in a community. This is because during its performance, members come together to dwell in harmony. The focus of this study is to help students to understand these musical types hence be able to appreciate them within their environment. In addition, to find out which of the musical genres they like so that, that musical type could be used as a teaching and learning strategy in delivering lessons to them.

This study has come at the right time when the world is battling with the Covid 19 pandemic with educational institutions hardly hit. So this study has become necessary as the musical type that majority of the students are familiar with could be used as a medium to reach out to them in terms of teaching and learning.

\section{Statement of Problem}

There are many musical types that are found in the Ghanaian society nowadays. They are performed in churches, festivals, schools as well as during funeral rites. But much empirical work has not been done by scholars to analyze these musical types according to the taste and preference of the users of these musical types in society. Once the musical preference and taste of the users especially the youth are identified, the genre could be used to communicate to them as well as educating them in the way they would understand. Especially in the midst of the global Covid 19 pandemic where the academic calendar and the mode of lesson delivery have changed to meet the current situation, one could think of musical genres which are integral part of society to step in to serve as a medium in the teaching and learning situation. Unfortunately, enough has not been done by researchers to use the music of the learners to serve as a teaching and learning medium. It is in this regard that this study is carried out to identify the differences in the musical types as well as identifying the musical preference of these students so that their choice of musical type could be easily used as a tool to communicate with them on academic, social, moral and other pressing issues on campuses and society at large. 
Research Questions

1. What are the differences in Art, Popular and Traditional musical genres in Ghana?

2. Which musical genre is more preferred among the students of SDA-Koforidua, St Francis- Hohoe and St Monica's - Mampong Colleges of Education in Ghana?

\section{Objectives of the Study}

1. To discuss the differences between Art, Popular and Traditional musical types in Ghana.

2. To explain the level of taste and preference of these musical types among students of SDA, St Francis and St Monica's Colleges of Education in Ghana.

\section{REVIEW OF RELATED LITERATURE}

\section{Concept of Art, Popular and Traditional Musical types}

\section{Traditional music}

Music as an arrangement of sounds manifest in many forms; with one of them being identified as traditional music. Many music scholars expressed their views about this musical type as follows:

Agordor (2004) explains that, traditional music is the oldest musical type in the African setting. He defends this point that, before the arrival of the European who brought Formal education including Western Music, traditional music was in existence; pure in its state. He further posit that, traditional musical type is free from any form of Western acculturation. $\mathrm{He}$ concludes that traditional music is the type that is associated with the indigenous people, and has remain so even in the midst of influence from other Western musical types.

Dzansi- Mcpalm (2006) also shares her thoughts that traditional music reflects themes and ideas from the immediate environment of the people. She discusses further that these themes are seen manifesting through the performing arts such as music, dance and drama. According to Kquofi et al (2015, traditional music has a link with the traditional or indigenous establishments such as chieftaincy, festivals, funerals and other social events. They discussed in addition that these traditional events when being observe are bound to see traditional music accompanying them. They cite an example for chieftaincy where revered traditional leaders are exalted or dignified with certain musical ensembles such as Kete ensemble being used to dignify Asantehene as well as Akpi or Adevu musical type for the exaltation of chiefs in in the Volta Region.

Traditional music is the type that feature on traditional events such as funerals. This assertion is according to Asare (2016). Asare cites an example of the people of Asante Mampong that they perform Ndwonkro traditional musical type during their funeral rites.

In confirming the thoughts of the earlier scholars, Brewu (2009) also discusses that, traditional musical type is performed by people that have common cultural traits and philosophy. He adds that, traditional music is associated with rites of passage in the Ghanaian traditional setting. He gives example of the Patakro traditional area where Adowa and Nwonkro traditional musical ensembles are used to accompany Marriage and death ceremonies respectively.

The views of Oppong (2013) are as well that, the musical type under review is the type that is available for use generally by a community. He confirms the assertion of the earlier writers that the traditional music is performed during funerals, weddings, parties and other recreational events. He discusses further citing example of Lunsi traditional musical type performed by the Frafra people of Ghana that the music is associated with their social functions such as the ones mentioned above.

The views of Ebeli (2016) express that, traditional music is the type that serves as a conduit through which the sentiments and emotions of a society is expressed. An observation which confirms the assertion of Dzansi- Mcpalm (2006).

With the views from all the scholars above, it could be deduced that traditional music is that type that is performed by indigenes based on their culture, doctrines and philosophies. It could further be explained that, this musical type is functional in a sense that all the traditional events that go on in the society have their counterpart musical types that go with them. Further inferences from the scholars could mean that traditional music is the reflection of the lives of people in a society.

Perspective of Ndah (2018) on Art, Popular and Traditional musical types

Art Music: This is the type that is normally written taking into consideration all the rules and principles of music. Art music or choral music is notated and it's performance is dictated by the composer. This indicates that, it is written and performed the way the composer wants it to be performed without adding or subtracting from what is written down. Example is the patriotic song in Ghana yèn ara asase nni (Land of our birth) by Ephraim Amu. Even though Amu is no more, the music remains to be performed the way it's been written down. Another example of art music is mida akpena Mawu (Give thanks to God) by Kenn Kafui.

Popular Music: This musical form doesn't necessarily employ all the principles or the rules in music. It may or may not be notated down but is widely enjoyed by many in the society. The challenge that usually confronts this musical type is people adding their own themes which the original composers or performers did not add to the music. A wide range of musical types fall within this category. Examples of some musical types considered as popular are high life, hiplife, and gospels. Some titles of popular music in Ghana are Onapo by De Adza, Jtan hunu by Dobble, Bribigyegyewo by Daddy Lumba, Mad over you by Runtown and If by Davido. 
Traditional music: This is a type that has its link from the traditional usages such as the wise sayings, philosophies, and proverbs in addition to institutions such as chieftaincy, festivals and funerals. These musical types are owned by the communities in which they are performed. Unlike the art musical type which is owned by individual composers, traditional musical types belong to all members of the communities. In Ghana, traditional musical types are associated with the ethnic groups. For example Kundum traditional ensemble is associated with the people of Nzema, whilst Adowa / Adzewa are linked to Asante and Fante people respectively. Others are Kpalongo and kolomashie by the Ga people, as well as Borborbor among the Ewe people not forgotten, Takai been associated with the people of Dagomba. It is worth noting that, whenever traditional music is been performed, any member of the community among the audience is permitted to associate with the ensemble and can therefore join the performers to either sing or dance. Because this musical type is linked to traditional events, they are performed normally during chieftaincy activities, funerals, and outdooring and other life cycle events.

Effects of song text in musical ensembles in Ghanaian societies

Those type of ensembles which have lyrics or songs accompanying them are not just there for the sake of performing. Brewu (2009) makes it clear that, before the country Ghana came into contact with the European, and for that matter their music especially; music was already an integral part in the religious, social, economic, cultural and political developments of the various ethnic groups. He gives an example that the work songs among the people along the coast are performed to motivate the fishermen to draw or pull or mend their nets at the beach. Brewu explains further that, song texts are one of the obvious sources for understanding human behaviour in relation with music. He shares again that, songs serve as a medium through which creative verbal expressions are stated to reflect both personal and social experiences.

He stresses a point that, music and language are related and that music is always affected by language. One strong feature of song text in Africa as He puts it is that the individual or a group could express deep-seated feelings not permissibly verbalized in other contexts. This statement Brewu continues by explaining the thoughts of Agordor (2004) on the song texts by explaining that Song texts in Africa are sometimes a reflection of the concerns of culture of the people which contribute to the correction of those aspects of behaviour that call for attention. He adds that, the song texts serve as a direct social control, that is, they are sometimes used through administration, ridicule and in some cases even more direct action, to effect actual changes in the behaviour of erring members of the society.

Teyi (2010) confirms Brewu (2009) by explaining that, songs texts are powerful tools used for recording historical events in society. He gives an example of the migration of the Ewes from Notsie to their present settlement, which in songs narrates this historic event to the younger generation. DzansiMc-Palm (2006) identifies the text of music in general as highly educative in society. She describes these texts as "rich stores" from which the society draws its social, moral and spiritual support. She adds also that song texts in music are closely related to the people and their way of life. She clearly states that the song texts are used to teach dignity of life, therefore preventing stealing and cheating. According to Matczynski (2011), song lyrics do in fact occupy an important space or contemplation and dialogue in Ghana. He argues that stories and proverbs are integrated into songs in service of moral lessons, social critique, advice and other didactic objectives.

Wuaku (2004) also makes his input concerning lyrics of songs and opinesthat, the lyrics of songs disclose messages suitable for funerals, for joyful moments, highly philosophical sayings geared towards good moral upbringing, love related songs and also Christian tunes serving as a reminder of congregational commitment to Christ. According to Agordor (2004) the texts of Amu's songs are a reflection of his experiences and of his inner life, his sensitivity to morality, his feeling of nothingness of man before God his creator, service of man to fellow man and his search for ultimate serenity of heart and mind. He describes them further by saying they are of certain meditative order; and that the texts are always addressing the society. He categorizes the lyrics of Amu's songs as philosophical, sacred, secular or patriotic. Agordor attributes the popularity of Amu and his music to the emotive and affective nature of his texts; since Ghanaian aesthetic theory is an integrated one involving ethical, religious as well as emotive aspect.

Adu-Agyem et al (2010) equally explain that, songs are essential elements in Bassari ceremonial occasions through which messages are communicated to inspire or caution the audience in question. The researchers stress their views that songs in African sense have contextual meaning that can significantly influence the lives of the people by reinforcing their beliefs and the values in the community. They discuss as well that, songs and dances are sources of inspiring and cautioning members of the society; besides, they state that they are means by which the society express grief and joy depending on the situation. They note that songs are inseparable forms of artistic and emotional expressions. They discuss further that songs are usually proverbial, educating, motivating and sometimes challenging.

Differences between Art, Popular and Traditional Musical Types

With the influx of migration, urbanization and acculturation, different types of musical types are found in Ghanaian communities these modern days. So it is very important for one to be able to distinguish traditional music from other genres. 
Matzcynski (2011) reveals that musical types in Ghana are divided into three namely traditional, popular and art music. He explains that, traditional music is the one that is characterized by a large degree of diversity in terms of styles, instruments and social functions, reflecting Ghana's own tremendous ethnic diversity. He adds that, the traditional music distinguishes itself from other musical types by its unique social functions and its integration into the everyday life of the community. In terms of the types of the instruments used in the traditional music in Ghana, he identifies broad categories as aero phones, chordophones, membranophones and idiophones not forgetting human voice.

Matzcynski (2011) shares with Brewu (2009) that, by saying that traditional music is indigenous to a particular ethnic groups or society, and in the case of Ghana, they are those that are connected with life cycle events such as birth rites, puberty rites, marriage ceremonies and funeral rites. He points out also that, some are also linked with socio-political institutions like enstoolment and destoolment.

Popular music is another type of music Matczynski (2011) revealed in his study. He points out Highlife as an example of this type of music. He argues out the classification of highlife by John Collins as

1. Dance- band highlife

2. Guitar- band highlife

On Popular music, Saighoe (1996) describes it as the type that show a preponderance of African musical elements married to those of western musical practices. He mentioned some of these types as the highlife of Africa, Juju music of the Yoruba of Nigeria, Kwella jive of Zimbabwe and some music traditions of both the orthodox and syncretic Christian churches.

The third musical type has been identified as Art music. This according to Matczynski (2011) emerges in the $20^{\text {th }}$ century in Africa, with the pieces generally situated within the traditions of western art music, composed using staff notation, played by professional musicians, and performed in a concert setting for an attentive audience. This explanation has been accepted by Teyi (2010) who also comments that Art music is the type that is created using written notation of the west. He emphatically states that art music in Ghana employs the combination of western musical symbols and African elements. He supports contributions made by earlier researchers by revealing that this musical type is mostly enjoyed by a well- behave and seated audience. For the differences to come clear between traditional music and other musical types, Brewu (2009) quoted to that effect. It is illustrated below:
Table 1: The difference between Art music and Traditional music

Art music

Traditional music

\begin{tabular}{|l|l|}
\hline \multicolumn{1}{|c|}{ Music is noted } & \multicolumn{1}{c|}{1.} \\
\hline $\begin{array}{l}\text { 2. Performers are separated from the } \\
\text { audience }\end{array}$ & $\begin{array}{l}\text { 2. Performers and audience are all } \\
\text { one }\end{array}$ \\
\hline $\begin{array}{l}\text { 3. Performers are limited in number } \\
\text { while the audience are not limited in } \\
\text { number }\end{array}$ & $\begin{array}{l}\text { 3. Audience form part of the } \\
\text { performers }\end{array}$ \\
\hline 4. Music is created and own by one & $\begin{array}{l}\text { 4. Music is owned by the } \\
\text { community in which the music is } \\
\text { created }\end{array}$ \\
\hline $\begin{array}{l}\text { 5. Music is divorced from aspect of } \\
\text { daily life activity }\end{array}$ & $\begin{array}{l}\text { 5. Music has formed an integral part } \\
\text { of everyday life }\end{array}$ \\
\hline $\begin{array}{l}\text { 6. The instruments are grouped as } \\
\text { strings, woodwind, brass, keyboards } \\
\text { and percussions }\end{array}$ & $\begin{array}{l}\text { 6. The instruments are grouped as } \\
\text { idiophones, chordophones, } \\
\text { membranophones and earophones }\end{array}$ \\
\hline $\begin{array}{l}\text { 7. There is little or no use of hand- } \\
\text { clapping }\end{array}$ & $\begin{array}{l}\text { 8. Hand -clapping is regarded as an } \\
\text { idiophonic device in making music }\end{array}$ \\
\hline $\begin{array}{l}\text { 8. It has at any moment one } \\
\text { rhythmic pattern in command. }\end{array}$ & $\begin{array}{l}\text { 8. Use of complex rhythms, poly- } \\
\text { rhythms are common. }\end{array}$ \\
\hline 9. There is unified performance. & $\begin{array}{l}\text { 9. There is independence of } \\
\text { instruments in performance }\end{array}$ \\
\hline $\begin{array}{l}\text { 10. Art music sometimes modulates } \\
\text { to other keys }\end{array}$ & $\begin{array}{l}\text { 10. Melodies are mostly short and do } \\
\text { not in normal case modulate }\end{array}$ \\
\hline
\end{tabular}

Source: (Brewu 2009)

Table 2: Difference between Art Music and Popular Music could be viewed below in a tabular form:

ART MUSIC

POPULAR MUSIC

\begin{tabular}{|l|l|}
\hline Music is always notated & Music is sometimes not notated \\
\hline $\begin{array}{l}\text { Music is always owned by a } \\
\text { composer }\end{array}$ & $\begin{array}{l}\text { Music could be written by a } \\
\text { composer and performed by a } \\
\text { different artiste }\end{array}$ \\
\hline $\begin{array}{l}\text { Music is written based on rules and } \\
\text { principles }\end{array}$ & $\begin{array}{l}\text { Music more often do not obey those } \\
\text { compositional rules }\end{array}$ \\
\hline $\begin{array}{l}\text { Modulations are well orchestrated in } \\
\text { Art music }\end{array}$ & $\begin{array}{l}\text { No deliberate modulations are } \\
\text { infused in Popular music }\end{array}$ \\
\hline $\begin{array}{l}\text { Performers of Art music are always } \\
\text { well behaved on stage }\end{array}$ & $\begin{array}{l}\text { Popular Musicians more often } \\
\text { perform in rowdy environment on } \\
\text { stage }\end{array}$ \\
\hline $\begin{array}{l}\text { There is proper costume for its } \\
\text { performance }\end{array}$ & $\begin{array}{l}\text { Any dress code is used during } \\
\text { performance }\end{array}$ \\
\hline $\begin{array}{l}\text { Performers are separated from the } \\
\text { audience }\end{array}$ & $\begin{array}{l}\text { Audience and performers are } \\
\text { involved in the performance }\end{array}$ \\
\hline
\end{tabular}

Table 3: Difference between Art and Traditional musical types

\begin{tabular}{|l|l|}
\hline \multicolumn{1}{|c|}{ Art Music } & \multicolumn{1}{c|}{ Traditional Music } \\
\hline Music is notated & Music is transmitted orally \\
\hline Music has a composer & $\begin{array}{l}\text { Music is owned by the whole } \\
\text { community }\end{array}$ \\
\hline Deliberate modulations exist & Mostly no modulations \\
\hline $\begin{array}{l}\text { Performers are separated from the } \\
\text { audience }\end{array}$ & $\begin{array}{l}\text { Audience and performers are treated } \\
\text { alike }\end{array}$ \\
\hline $\begin{array}{l}\text { There are prescribed costume in its } \\
\text { performance }\end{array}$ & $\begin{array}{l}\text { There are traditional costume to } \\
\text { match with some ensembles }\end{array}$ \\
\hline $\begin{array}{l}\text { Composed using principles and rules } \\
\text { of music }\end{array}$ & $\begin{array}{l}\text { Do not obey any formal musical } \\
\text { rules }\end{array}$ \\
\hline
\end{tabular}

Source: (Ndah 2018)

Collins (2016) shares that, the traditional musical type is ethnic or rural oriented as that has a link with the traditional indigenes. He states also that, the themes of traditional 
musical type are often orally transmitted and performed mostly by their folk or peasant. And it is communal or owned by the whole community; an assertion that is in agreement with Ndah (2018). He opines also that, the audience are also considered part of the performance. He adds that, such ensemble more often performs social functions and made use of home made instruments.

For the Art musical type, he explains that, it is enjoyed by the urban and national space. It is transmitted through a printed score and is performed by the elite or the middle class. He describes this musical type as serious and owned by individuals who usually copy right their pieces. They are directed by a conductor or a Virtuoso he argues. In addition, he clarifies that, the audience under this musical type are separated from the performers.

He describes the popular type as being urban or transnational oriented in terms of location of performance. He states that, they are transmitted in the recordings in the mass media. He describes it in terms of status as non - serious or frivolous and that, it is performed by super stars mostly on electronic media. $\mathrm{He}$ adds further that, the audience are mostly the listeners of TV, Radio and other mass media. Collins adds further that, the patrons of popular music in Africa are skilled and semiskilled, artisans, transport workers, seamen, traders, civil servants etc. He opines that, the popular musical type always draws the youth along with its dynamic features. He continues that, the lyrics of popular musical types reflect immediate events and sentiments of the people. He cites example that, because popular music pulls the youth along, it was used in the struggle for Ghana's independence by the CPP and Kwame Nkrumah.

It could therefore be deduced from the scholars that, Art musical type is notated and is performed strictly according to lay down principles, while the popular is more flexible in its performance as is mostly played on other media. And the traditional folkloric is ethnic based in its performance

\section{METHODOLOGY}

The research being qualitative oriented, adopted descriptive technique to bring out the themes in the study.

\section{Research tools}

Some of the research tools adopted during the study were:

- Interview

- Observation

- Questionnaire

Interview and questionnaire were used to solicit data from Students from SDA College of Education, Koforidua, St Francis College of Education in Hohoe as well as St. Monica's College of Education, Mampong Ashanti. The interview was very useful as it gave room for the interviewees to give out more information related to the topic under study. Interview guide was used to guide in the course of questioning, bearing in mind the focus of the study.
Questionnaire was equally helpful especially for those respondents who could not appear during the interview session to as well express their thoughts on the subject under study.

Observation was as well used to gather data by the researchers towards this study. This instrument helped the researchers to have firsthand information about the performances which normally go on during entertainment and socialization events on campus. The researchers observed the musical types that are dominant during all socialization events on campus. For the sampling methods used, Random and Convenience were used to sample from the target population consisting of Students of SDA, St. Francis and St Monica Colleges of Education in Ghana. 300 Students were available for the study hence became the Total population. Random technique was used because to the best of the knowledge of the researchers, all the target population had the same characteristics and any student could be very useful for the study. Convenience sampling technique was equally employed because of the current arrangement of Colleges where two groups of students are permitted in residence for face to face learning whilst another group would be at home engaging in online learning; all as a result of the Covid 19. The researchers therefore took advantage of those students who were available on campus at the time to help in the study.

\section{Analysis of Data}

\section{Responses from St Monica's College of Education}

As to the differences in the musical genres, 50 of the 100 respondents were able to explain that, Art music is written on paper and sung in churches or theatres by choirs; whilst traditional ones are those that are performed during traditional festivals in communities. They added that, popular musical types are the ones that are performed during recreational or leisure activities. The rest of the respondents as well explain that, Art music is performed in churches whilst popular one is performed at Pub, restaurant and beaches. The traditional music is performed during cultural events such as festivals they added.

When they were asked which of the musical types they like or prefer most, 70 of the respondents representing $70 \%$ chose Popular Musical type. Twenty of them (20\%) had the like for Art musical genre and 10 of them thus $10 \%$ had interest in Traditional musical type.

In justifying their choices, those who had the preference for popular musical type explained that, it is flexible and free to perform without any restrictions. Those who opted for the Art music also shared that, it is strictly performed to rules thereby making it authentic. For those who chose the traditional type, they argued that, the type helps to showcase culture of society. The musical preference of the respondents in this category is substantiated in a tabular form below: 
Table 4: Musical preference of students of St Monica's College

\begin{tabular}{|c|c|c|}
\hline Musical type & $\begin{array}{c}\text { Number of } \\
\text { respondents }\end{array}$ & Percentage \\
\hline Popular & 70 & $70 \%$ \\
\hline Art & 20 & $20 \%$ \\
\hline Traditional & 10 & $10 \%$ \\
\hline
\end{tabular}

Total Population for this category $=100$

\section{Responses from SDA College of Education}

100 students responded to the questionnaire. In differentiating between Popular, Art and Traditional musical types, all of them were able to state that, popular music could may or may not be notated using the musical notes but is flexible and widely enjoyed by majority in society. They shared further that, for the Art music, it is written or notated on a musical staff and its performance is strongly done according to the wish of the composer. They added that, traditional musical genre is the type that is linked to the culture and traditions of a particular society.

As to which of the musical genre they have taste or preference for, 77 of them thus $77 \%$ opted for Popular musical type. Twenty of them (20\%) have preference for Art musical type and 3 of them representing 3\% chose Traditional type.

In defending their choices, those who opted for popular musical type stated that, its performance do not strictly adhere to compositional rules and principles. And for that matter, popular music makes room for improvisation hence brings flexibility. They added that, it can be performed at secular functions and because of that attract a lot of audience.

For those in favour of the Art music, they stated that it is authentic and serious in a sense that, what the composer puts down cannot be altered by other artistes in the name of improvisation or remix. For the traditional music lovers, they argue that, it gives society its cultural identity hence found at most life cycle events. The views of the respondents in this category are equally represented on a table below:

Table 5: Musical taste of the students of SDA College

\begin{tabular}{|c|c|c|}
\hline Musical genre & $\begin{array}{c}\text { Number of } \\
\text { respondents }\end{array}$ & Percentage \\
\hline Popular & 77 & $77 \%$ \\
\hline Art & 20 & $20 \%$ \\
\hline Traditional & 03 & $3 \%$ \\
\hline
\end{tabular}

Total Population in this category $=100$

\section{Responses from St Francis College of Education}

In giving the differences between Popular, Art and Traditional musical types, the respondents were able to explain that, for the popular music, it takes into account the joy of the audience; especially the youth. Therefore, it performs to entertain the audience; hence there are no restrictions and rules to the performances.
They as well explained the Art musical genre as the type which is written or notated on a musical staff; observing all rules and principles in musical composition. They added that, the musical type is performed just as it is written. Nothing is added or subtracted from how it has been written. For the traditional musical type, they all shared that, they draw their themes from the customs, culture and the philosophy of society in which such musical type is performed.

On which of the musical type they like most, $50 \%$ of them expressed like for the popular musical type. For the Art type, 35 respondents representing 35\% opted for it, whilst the traditional type has 15 respondents, representing $15 \%$.

As to why they have the like for their choices, those for the popular type shared that, it is easy to perform and it attracts the youth more than any other musical type. For those who have support for the Art type, they argued that, there is exhibition of scholarship in such musical type since one has to critically think and observe rules before writing such musical type. Those for the traditional genre as well shared that, such musical type defines and give cultural identity to a particular society. The overall musical preference of the respondents in this category is represented on a table below:

Table 6 :Musical preference of students of St Francis College

\begin{tabular}{|c|c|c|}
\hline Musical type & $\begin{array}{c}\text { Number of } \\
\text { respondents }\end{array}$ & Percentage \\
\hline Popular & 50 & $50 \%$ \\
\hline Art & 35 & $35 \%$ \\
\hline Traditional & 15 & $15 \%$ \\
\hline
\end{tabular}

Total population for this category $=100$

In consolidating data from the three colleges where the study was done, the musical taste and preference of the respondents could further be seen below:

Table 7: Musical preference of the total population of the study

\begin{tabular}{|c|c|c|}
\hline Musical type & $\begin{array}{c}\text { Number of } \\
\text { respondents }\end{array}$ & Percentage \\
\hline Popular & 197 & $66 \%$ \\
\hline Art & 75 & $25 \%$ \\
\hline Traditional & 28 & $09 \%$ \\
\hline
\end{tabular}

Total population for the study $=300$

\section{DISCUSSION OF FINDINGS}

Through observation, the researchers equally noticed that, many of the students do not show much interest in the performance of the Art Music. That manifest in their behavior to the extent that, many of them do not belong to the College choirs where a lot of Art musical types are rendered. But whenever it is time for entertainment programmes which are normally done during Saturday evenings of every week in the Colleges, as well as other socialization events on campus, they become so excited when popular music is performed. 
It could therefore be deduced from the study that, Art musical type is truly the type which is written down to be performed strictly to rules as depicted by the composer in a musical piece. It could be equally added that, Art musical type is always notated on a music staff. Whilst Popular type do not necessarily need any rule or principle within which to perform. In other words, that musical type is open for improvisation as it focuses on the taste of the audience. And the Traditional type is performed with links to traditions and culture within ethnic orientations.

The study equally discussed that the students in the study area are more interested in popular musical type than the other types because of the freedom and flexibilities that are attached to it's performances. This study has truly confirmed the studies of the earlier scholars such as Collins (2016), Ndah (2018) Brewu (2009) and Agordor (2004) who all gave explanations on the types of the musical genres under study. It equally confirms the assertion of Collins that, majority of the Ghanaian populace are inclined to popular musical type.

\section{CONCLUSION}

The focus of the study was to differentiate between Art, Popular and Traditional musical types and also to find out the level of taste and preference of students whenever Art, Popular and Traditional musical types are performed. The study however revealed that, Art Music is normally written taking into consideration all the rules and principles of music. And Art music or choral music is notated and its performance is dictated by the composer. This indicates that, it is written and performed the way the composer wants it to be performed without adding or subtracting from what is written down. Popular musical form doesn't necessarily employ all the principles or the rules in music. It may or may not be notated down but is widely enjoyed by many in the society, whilst Traditional music has its link from the traditional usages such as the wise sayings, philosophies, culture and proverbs in addition to traditional institutions within society.

The study revealed that the majority of the population (66 \%) in the research area have like for popular musical type over the other two musical types.

\section{RECOMMENDATIONS}

- Educational policy makers should design students' learning resources with embedded Ghanaian Popular musical types so as to attract them to their lessons.

- Musicians should be guided to pick educational themes from within their setting to compose their music so that, the contents of the songs should have positive impact on students since such musical types are the preferred choices among them.
- Teachers in the Colleges of Education in Ghana should be encouraged to teach their concepts using popular music within the setting of the students. Confirming the assertion of Brewu (2009) that, song texts serve as a tool through which creative verbal expressions are stated to reflect both personal and social experience.

- Popular musical types could be used with crafted messages to serve as means of advising the students on issues of academic and morality. A stance in consonance with Agordor (2004) that Song texts in Africa are sometimes a reflection of the concerns of culture which they are part; and that they contribute to the correction of those aspects of behaviour to which they call for attention. Also, they serve as a direct social control, that is, they are sometimes used through administration, ridicule and in some cases even more direct action, to effect actual changes in the behaviour of erring members of the society.

\section{REFERENCES}

[1] Agordor, A.A. (2004). The music of Amu and Nayo. AccraMadina: Royal Gold Publishers Ltd.

[2] Adu-Agyem, J, Mani,E. (2010) Bassari Fire Dance As a source of cultural tourism. Asafo- Kumasi: MISPA Graphics.

[3] Asare, D (2015) Evolution of Traditional Funeral songs among the inhabitants of Asante Mampong. Thesis submitted to the school of Graduate studies, KNUST.

[4] Brewu, J. (2009). Role and Importance of traditional music in Patakro culture. Thesis Submitted to the School of Graduate studies Kwame Nkrumah University of Science and Technology. Retrieved from http://dspace.knust.edu.gh.

[5] Collins, J (2016) Popular Music performance and Culture in Ghana, the past 50yrs. Ghana Studies. 10 (9-64)

[6] Dzansi-Mcpalm, M. (2006). Artistic- Aesthetic in-put of song leaders in African Ensembles: A case of Zigi in Ghana, International Journal of community music. Retrieved from http://www.intellectbooks.co.uk.

[7] Ebeli, E.A (2015) Communication processes in Totoeme music of the Avatime people of Ghana. International journal of African society cultures and traditions Nos 5(3). Retrieved from www.eajournals.org

[8] Matczynski, W. (2011). Highlife and its roots: Negotiating the social, cultural and musical continuities between popular and traditional music in Ghana. Retrieved from http:// digital commons. Macalester.edu/music honors

[9] Ndah, D, S (2018) Reference Book for Music Directors and Instrumentalists. Ashanti Mampong: John Ray Publishers

[10] Oppong, E (2013) The Lunsi Traditional music of the Frafras in Tamso. Thesis submitted to the University of Ghana. Retrieved from ugspace.ug.edu.gh

[11] Saighoe, F.A.K. (1996). Traditional African music in Black American socio-cultural interaction. A historical perspective. The journal of African music Educator (8). Retrieved from http://www.scientific_african.org.

[12] Teyi, N. G. (2010). A text book of Music for senior High Schools and Colleges. Kumasi: Adonai Publication.

[13] Wuaku, H.M. K. (2004). Compositional techniques of the Egbanegba musical type Restricted to the Peki- Avetile area; a dissertation submitted to the University of Ghana.Retrieved from http:// aatpm.com. 